\title{
Determination of heavy metals concentration in Astragalus anisacanthus and Ebenus stellata of Balochistan, Pakistan
}

\author{
Imran Kiazai ${ }^{1}$, Samiullah ${ }^{1 *}$, Naqeebullah Khan ${ }^{1}$, Attiq-Ur-Rehman ${ }^{1}$, \\ Abdul Ghaffar ${ }^{1}$ and Abdul Baqi ${ }^{1,2}$ \\ 1. Department of Chemistry, University of Balochistan, Quetta 87300-Pakistan \\ 2. Colleges Higher and Technical Education Balochistan, Quetta 87300-Pakistan \\ *Corresponding author's email: sami435889@yahoo.com
}

Citation

Imran Kiazai, Samiullah, Naqeebullah Khan, Attiq-Ur-Rehman, Abdul Ghaffar and Abdul Baqi. Determination of heavy metals concentration in Astragalus anisacanthus and Ebenus stellata of Balochistan, Pakistan. Pure and Applied Biology. Vol. 8, Issue 3, pp2028-2035. http://dx.doi.org/10.19045/bspab.2019.80147

\begin{tabular}{llll}
\hline \hline Received: 18/05/2019 & Revised: 15/07/2019 & Accepted: 17/07/2019 & Online First: 25/07/2019 \\
\hline
\end{tabular}

\section{Abstract}

Various elements along with heavy metals, present in different medicinal plants, play important roles in human's life. Assuming this, the concentrations of nine different elements including heavy metals were analyzed in selected medicinal plants i.e. Astragalus anisacanthus and Ebenus stellata. Wet digestion method was performed for the mineralization of plant samples employing three strong acids such as sulphuric acid $\left(\mathrm{H}_{2} \mathrm{SO}_{4}\right)$, nitric acid $\left(\mathrm{HNO}_{3}\right)$ and per chloric acid $\left(\mathrm{HClO}_{4}\right)$ in ratio of 1:5:0.5mL respectively followed by filtration and analysis by flame atomic absorption spectroscopy. For $\mathrm{Na}$ and $\mathrm{K}$, flame photometer was used and samples were diluted up to hundred folds for obtaining results within the range of the instrument. The increasing order of concentration of elements in A. anisacanthus is as: $\mathrm{Cd}<\mathrm{Pb}<\mathrm{Co}<\mathrm{Ni}<\mathrm{Cu}<\mathrm{Mn}<\mathrm{Fe}<\mathrm{K}<\mathrm{Na}$, whereas in E. stellata was found as: $\mathrm{Cd}<\mathrm{Co}<\mathrm{Ni}<\mathrm{Cu}<\mathrm{Mn}<\mathrm{Pb}<\mathrm{Fe}<\mathrm{K}<\mathrm{Na}$. The accumulation of heavy metals in plants was different in concentration according to the study. Furthermore, the concentrations were also within the range established by international organization. In future, the usefulness of this research work is that it will result in the synthesis of many new drugs as well as it will also be used for providing public protection regarding the adverse effects of heavy metals.

Keywords: Flame atomic absorption spectroscopy; Flame photometer; Flame emission spectroscopy; Heavy metals; Wet digestion

\section{Introduction}

Plants are mainly photosynthetic eukaryotic multicellular organisms which belong to kingdom plantae. They are comprised of conifers, flowering plants and gymnosperms [1]. The term "medicinal plants" refers to a large group of plants which are used in the field of herbalism [2]. Elements which are not necessary for plant growth, but which can affect the production of crops, animals and human health are becoming increasingly important [3]. Some elements are known as micronutrients or trace elements which play 
important role for plant's growth including $\mathrm{Zn}, \mathrm{Ni}, \mathrm{Mn}$, etc. [4].

Determination of necessary elements present in plants and soil is essential if products are to be regulated at highly efficient production level [2]. For the human body, to maintain good health, metallic and non-metallic elements are needed. Subsequently, the elemental composition in edible plants and food is necessary for knowing their beneficial significance $[\mathbf{5 , 6 - 8}]$. There are 92 naturally occurring elements. Almost 30 metals and metalloids are fatal to human beings [9]. Heavy metals are member of specific subset of elements including transition metals, lanthanides and actinides [10]. When the heavy metal ions are absorbed through root system, they start to deposit on various part of plant resulting in the reduce growth of plants $[11,12]$. Heavy metals are not toxic at low concentration, but when the concentration reaches to the threshold stage causes damage to human body [4].

Among heavy metals, $\mathrm{Pb}$ is one of the most abundantly found element on earth crust [13]. The environmental pollutants include the heavy metals except the natural calamities. The anthropogenic activities include the adverse effects of heavy metals on the environment [11]. Many plant species have been used for numerous infectious diseases ranging from minor infection to dangerous ailments like skin, asthma and horde of indication [14]. As stated by WHO report, about $70-80 \%$ of world population still primarily depends upon the non-conventional medicines, which are derived from herbal plants [5]. About 33 million people use medicinal plants in developing countries to treat various diseases [2]. The traditional medicine exercise is extensively employed in China, India, Japan, Sri Lanka and Thailand. The traditional tribal medicine in China is attributed by medicine consumption of about $40 \%$ [15].
Pakistan has specific climatic region and great biodiversity. About 6,000 types of higher plants are present. It has been reported that 600-700 species of which are used as medicinal plants [16]. The climate of Balochistan, the largest province of Pakistan regarding area, makes it rich in diverse species of medicinal plants [2]. To determine the whole concentration of metals, cannot give the complete information about their forms, but to find out heavy metals which are different from other metals because these are non-biodegradable toxic chemical species [17].

Atomic Absorption spectroscopy (AAS) is a helpful method for the analysis of trace elements, because of its high specificity, low detection limit, simple to use and easy sample preparation [18]. AAS is highly sensitive and concentration of different elements can be determined at lower level of concentrations [19]. AAS is the most suitable method and accepted generally for elemental analysis [18]. In spectroscopy, we study the interaction of electromagnetic radiation (EMR) with sample followed by measuring the attenuation of EMR intensity [20]. The quantity of light absorbed at a specific wavelength will rise as the number of atoms of the selected element increases in the light path and thus is proportional to the concentration of the element [21].

Ebenus stellata belongs to family Fabaceae and class Magnoliopsida and is locally known as "Sassai" [22]. The extracts of many plants belonging to Fabaceae family have shown toxicity and among them, $E$. stellata has been found as the least toxic leading to its usage as an anti-convulsant [23]. E. stellata is used in a group of medicine called as anti-convulsant (antiepileptic drugs or anti-seizure drugs) [24].

A. anisacanthus is a eukaryotic plant belongs to kingdom plantae; division, tracheophyte; genus, vedler (Astragalus) 
and family, Papilionacaea [22]. Astragalus species contain a wide range of constituent including more than 40 saponins and several flavonoids including isoflavones and polysaccharides free from amino acids. $A$. anisacanthus is a neutral dietary source that is used for various adverse health conditions such as to treat common cold [22, 24]. Astragalus has been used as a traditional Chinese medicine for centuries. Its main use is to boost up the body immune system, to treat adverse health conditions like heart diseases [22, 24] and the folk people have employed these plants as medicine [22]. In this study, the concentrations of different heavy metals including $\mathrm{Cd}, \mathrm{Fe}, \mathrm{Ni}, \mathrm{Co}, \mathrm{Cu}$, $\mathrm{Pb}$ and $\mathrm{Mn}$ present in $A$. anisacanthus and $E$. stellata was determined using AAS analytical technique. Whereas, concentrations of $\mathrm{Na}$ and $\mathrm{K}$ was assessed by employing flame photometric technique.

\section{Materials and methods}

\section{Reagents and solutions}

Different analytical grade standards $\left(1000 \mathrm{mgL}^{-1}\right)$ of metals $\left(\mathrm{Cd}^{2+}, \mathrm{Fe}^{2+}, \mathrm{Ni}^{2+}\right.$, $\mathrm{Co}^{2+}, \mathrm{Cu}^{2+}, \mathrm{Pb}^{2+}$ and $\mathrm{Mn}^{2+}$ ) were purchased from Merck, Marker for the analysis of heavy metals. Working standard solutions (0.1$20 \mathrm{mgL}^{-1}$ ) of these metals were arranged by diluting the required aliquots from their stock solutions with the mixture of $\mathrm{H}_{2} \mathrm{SO}_{4}, \mathrm{HNO}_{3}$ and $\mathrm{HClO}_{4}$ in ratio of 1:5:0.5 respectively. For the digestion of plants, a mixture of acids $\mathrm{H}_{2} \mathrm{SO}_{4}, \mathrm{HNO}_{3}$ and $\mathrm{HClO}_{4}$ in ratio of 1:5:0.5 respectively was used. This mixture was arranged from the analytical grade commercially available stock solutions of these acids.

\section{Instrument and glassware}

Atomic absorption spectrophotometer (Thermo electron S4 AA) was used for the determination of heavy metals with hollow cathode lamps of different metals and a flame of air-acetylene. Whereas, $\mathrm{Na}$ and $\mathrm{K}$ were detected in aforementioned plants through flame emission spectrophotometer (Jenway
PFP7).Various glassware including round bottom flasks, conical flasks and beakers of pyrex glass were used. These glass wares were precleaned with surfactant, followed by soaking in $\mathrm{HCl}$ bath $(10 \% \mathrm{v} / \mathrm{v})$ for a week, and rinsing several times with deionized water.

\section{Sample collection}

Two medicinal plants were collected from Baberr Jungle situated in District Zhob, Balochistan in the month of August 2018 and recognition of the above-mentioned plants were done by a prominent taxonomist Dr. Rasool Bakhsh Tareen. Both plants were dried for almost two weeks in shadow or in absence of direct sun light. After the drying procedure, the medicinal plants were carefully grinded and prepared for further research work.

\section{Sample preparation}

The collected plants after drying were crushed into powder form via an electrical blender, which was used for further analysis through AAS and flame photometer. Digestion of the powdered plants was accomplished according to a previously reported protocol [25]. Accordingly, 0.25g powder of each plant was taken in a $50 \mathrm{~mL}$ round bottom flask and was then added $6.5 \mathrm{~mL}$ mixture of acids $(5 \mathrm{~mL}$ nitric acid, $1 \mathrm{~mL}$ sulphuric acid and $0.5 \mathrm{~mL}$ per chloric acid). These acids were taken from their commercially available stock solutions. Individually, each plant sample containing mixture of acids was heated on a hot plate (JENWAY 1000) at $80-85^{\circ} \mathrm{C}$ until white fumes come out from the flask. These white fumes indicate that the digestion have been completed. Successively, few drops of distilled water was added to it, removed it from the hot plate and allowed it to cool for about 5-10 minutes. The digestion mixture was then transferred into $50 \mathrm{~mL}$ volumetric flask and made the volume up to the mark i.e. $50 \mathrm{~mL}$ by pouring distilled water in it followed by filtration using filter paper 
Whatmann No.1 in the labelled plastic bottles. These prepared solutions after the wet digestion were studied for detection of elements using AAS and flame photometer. The dilutions of different concentrations were prepared from analytical grade stock standards of $1000 \mathrm{ppm}$ for the purpose of calibration. These dilutions were prepared immediately before running the samples. Deionized water was used throughout the investigation. FES of Jenway PFP7, the technique was applied for the evaluation of sodium and potassium. For obtaining results within the range of flame photometer, the samples were diluted 100 folds with deionized water.

\section{Result}

After analysis, the obtained results $\left(\mathrm{mgL}^{-1}\right)$ for $\mathrm{Cd}, \mathrm{Pb}, \mathrm{Co}, \mathrm{Ni}, \mathrm{Cu}, \mathrm{Mn}, \mathrm{Fe}, \mathrm{K}$ and $\mathrm{Na}$ are shown in (Table 1) and their comparison is given in (Figure 1).

Table 1. Concentration $\left(\mathrm{mgL}^{-1}\right)$ of various elements in selected medicinal plants

\begin{tabular}{|l|c|c|c|c|c|c|c|c|c|}
\hline Plant specie & $\mathbf{C d}$ & $\mathbf{P b}$ & $\mathbf{C o}$ & $\mathbf{N i}$ & $\mathbf{C u}$ & $\mathbf{M n}$ & $\mathbf{F e}$ & $\mathbf{K}$ & $\mathbf{N a}$ \\
\hline A. anisacanthus & 0.0145 & 0.0727 & 0.0986 & 0.1064 & 0.2579 & 0.347 & 14.10 & 582 & 753 \\
\hline E. stellata & 0.0162 & 0.726 & 0.0771 & 0.092 & 0.2044 & 0.629 & 14.098 & 514 & 698 \\
\hline
\end{tabular}

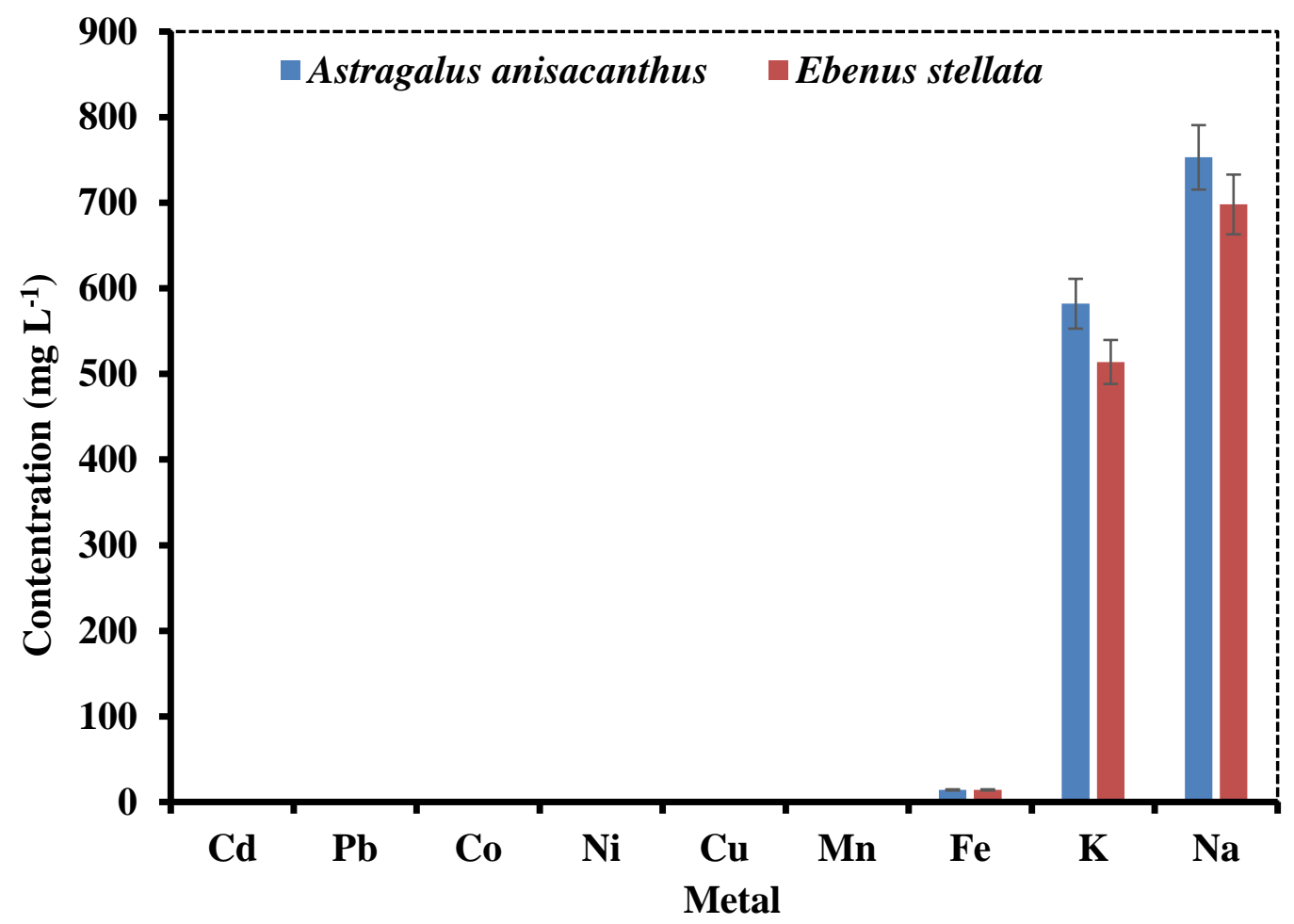

Figure 1. Comparison of the concentrations of various metals in A. anisacanthus and $E$. stellata

\section{Discussion}

AAS is used for the estimation of various heavy metals because of its accuracy. In addition, flame emission spectroscopy is a simple method for the determination of sodium and potassium. For $\mathrm{Na}$ and $\mathrm{K}$, samples were obtained by the dilution technique using deionized water considering the range of calibration curves of different elements. As AAS was connected with 
computer device and it gives calculated concentration of various elements upon detection whereas flame photometer was not able to give the calculated concentrations so, the concentration of sodium and potassium were obtained through the regression equation.

Satisfactory results were obtained through the wet digestion method for the mineralization of plant materials. This method eradicates the surrounding of organic compounds around the minerals, only the minerals are left behind in an aqueous solution by using the strong oxidizing agents. This method is simple and faster than other methods of digestion like dry ashing and microwave digestion.

Plants need copper for their growth and development [26]. Cu plays an important role in metabolic process retarding the growth of higher plants [27]. The ailments like wounds inflammation, chest and arthritis are mainly healed via the presence of copper in plants $[28,29]$. In addition, the existence and use of $\mathrm{Pb}$ makes it unique regarding to environmental toxicity that is why it is very important to study heavy metal like $\mathrm{Pb}$ [20].

Furthermore, the permissible limit of copper in plants is $10 \mathrm{mg} / \mathrm{kg}$ which is used remedially $2-3 \mathrm{mg} /$ day for the consumption of humans [30]. The concentration of $\mathrm{Cu}$ in A. anisacanthus was $0.2579 \mathrm{mgL}^{-1}$ whereas, in E. stellata $0.2022 \mathrm{mg} \mathrm{L}^{-1}$.

The mammals need cobalt in a very minor quantity. Cobalt can be used to treat anemic patients and also various cancers can be treated by the small amount of it $[28,29]$. Cobalt is a major part of vitamin B-12 [31]. The tolerable limit of cobalt for human intake is $1.6-8 \mu \mathrm{g} / \mathrm{kg}$ body weight per day [32]. The mean concentration of cobalt in $A$. anisacanthus was found as $0.0986 \mathrm{mgL}^{-1}$ and in E. Stellata was $0.0771 \mathrm{mgL}^{-1}$.

Nickel is vital for human body and also for plants in a very minute quantity as it is required for the insulin production. However, its deficit leads to liver malfunction. In its high concentration, it is detrimental and causes many ailments which includes cardiac, loss of body weight and liver problems. According to $\mathrm{WHO}$, the permissible limit of $\mathrm{Ni}$ is $1.5 \mathrm{mg} / \mathrm{kg}$ in the plants and for dietary intake it is $1 \mathrm{mg} /$ day [30]. The mean concentration of $\mathrm{Ni}$ found in A. anisacanthus was $0.1064 \mathrm{mgL}^{-1}$ and in $E$. Stellata was $0.0 .092 \mathrm{mgL}^{-1}$.

To produce red blood cells in human body iron is an essential element. Anemia is caused by the low quantity of iron in the human body [33]. The human body tissues are damaged due to the high amount of iron [34]. According to WHO, the acceptable limit of iron in plants is $20 \mathrm{mg} / \mathrm{kg}$ while 10 to $28 \mathrm{mg} /$ day for human consumption [30]. The mean concentrations of iron in $A$. anisacanthus and $E$. stellata were $14.10 \mathrm{mgL}^{-1}$ and $14.098 \mathrm{mgL}^{-1}$ respectively. Manganese play an important role in the growth of both plants and animals. It causes reproductive and skeletal problems due to its deficiency in mammals. In excessive amounts, it leads to several lung and brain complications [35]. According to WHO standards, the tolerable concentration of manganese for plants and animals are $200 \mathrm{mg} / \mathrm{kg}$ and $11 \mathrm{mg}$ respectively [30].

The mean concentrations of manganese in $A$. anisacanthus and $E$. stellata were $0.347 \mathrm{mgL}^{-1}$ and $0.629 \mathrm{mgL}^{-1}$ respectively.

Even in the low concentration, cadmium is toxic and non-essential heavy metal for human health. The impediments in learning and hyperactivity in offspring is all due to cadmium [36]. The permissible limit according to WHO for cadmium is in therapeutic plants is $0.3 \mathrm{mg} / \mathrm{kg}$ [30]. The average concentration of cadmium in $A$. anisacanthus and $E$. stellata were $0.0145 \mathrm{mgL}^{-1}$ and $0.0162 \mathrm{mgL}^{-1}$ respectively. 
Lead is a non-essential heavy metal. It is stored in the bones and teeth which causes the bones to become stiff and hard and is the reason of weakens of the limbs and wrists. The deposition of lead in the soft tissues, renal, immune, reproductive and nervous systems of the body affects their functions. The safety limit of lead for human consumption is $1.5 \mathrm{mgL}^{-1}[33,37]$. While in medicinal plants, the permissible limit is $10 \mathrm{mg} / \mathrm{kg}$ [30]. The average concentration of lead in A. anisacanthus and E. stellata were $0.0727 \mathrm{mgL}^{-1}$ and $0.726 \mathrm{mgL}^{-1}$ respectively. Sodium acts as a transporter for the substances which are involved in the respiration process such as amino acids, glucose and other metabolites. Mood swings, muscles cramps, dehydration and hair loss are some of the medical complications caused by the sodium deficiency. The recommended value of sodium for human intake is $13.8 \mathrm{mg} /$ day [38]. The average concentration of $\mathrm{Na}$ in $A$. anisacanthus and E. stellata were $753 \mathrm{mgL}^{-}$ ${ }^{1}$ and $698 \mathrm{mgL}^{-1}$ respectively.

Potassium is involved in the regulation of hormones, secretion of insulin and response of immune system. Potassium works to lower the blood pressure. It is involved in the remedy of liver and kidney problems. The permissible limit of potassium for woman and man is $2300 \mathrm{mg} /$ day and $3100 \mathrm{mg} /$ day respectively [39]. The average concentration of $\mathrm{K}$ in $A$. anisacanthus and $E$. stellata were $519 \mathrm{mgL}^{-1}$ and $698 \mathrm{mgL}^{-1}$ respectively.

\section{Conclusion}

This study showed that the concentration of heavy metals in plants such as $A$. anisacanthus and E. stellata is below from their secure limits given by different international organizations like FAO and WHO. Nine elements including essential and non-essential elements were estimated in these plants among which the concentration of sodium and potassium were found to be higher in both plants and concentration of heavy metals were within the permissible ranges. These plants are nontoxic to use as traditional medicines and therefore are not at danger. The accurate and precise determination of metals are very necessary. The results obtained in this investigation will be supportive for the manufacturers in the synthesis of new drugs with different combination of medicinal plants for curing various ailments.

\section{Authors' contributions}

Conceived and designed the experiments: I Kiazai, Samiullah, A Baqi \& A Ghaffar, Performed the experiments: I Kiazai \& A Baqi, Analyzed the data: Samiullah, N Khan \& A Rehman, Contributed materials/ analysis/ tools: A Rehman \& Samiullah, Wrote the paper: I Kiazai, A Baqi \& Samiullah.

\section{References}

1. Cavalier-Smith T (1981). Eukaryote kingdoms: seven or nine. Bio Systems 14(3-4): 461-481.

2. Singh R (2015). Medicinal plants: A review. J Plant Sci 3(1-1): 50-55.

3. Marschner H (1983). General introduction to the mineral nutrition of plants. J Plant Nutr Soil Sci: 5-60.

4. Pahlsson AM (1989). Toxicity of heavy metals $(\mathrm{Zn}, \mathrm{Cu}, \mathrm{Cd}, \mathrm{Pb})$ to vascular plants. Water Air Soil Pollut 47(3-4): 287-319.

5. Simone M, Fernando GC \& Maria LP (2012). Heavy Metals and Human Health, Environmental Health - Emerg Issue \& Pract ISBN: 978-953- 307-854$0 \mathrm{I}$.

6. Kurzydlowski KJ (1999). Structure and properties of metals. Acta Physica Polonica 96(1): 69-79.

7. Dar RA, Shahnawaz M \& Qazi PH (2017). General overview of medicinal plants: A review. The $J$ of Phyto Pharma 6(6): 349-351. 
8. Shinwari Z (2010). Medicinal plants research in Pakistan. $J$ of Med Plants Res 4(3): 161-176.

9. Long XYX \& Ni WZ (2002). Current status and perspective on phytoremediation of heavy metal polluted soils. J Appl Ecol 13: 757-62.

10. Kurzydlowski KJ, Ralph B, Bucki J \& Garbacz A (1996). The grain boundary character distribution effect on the flow stress of polycrystals. The influence of crystal lattice texture. Mater Sci Eng A 205(1-2): 127-132.

11. Singh R, Gautam N, Mishra A \& Gupta $R$ (2011). Heavy metals and living systems: An overview. Indian $J$ Pharmacol 43(3): 246.

12. Karnika AH, Reddy RS, Saradhi SV \& Singh J (2007). Biosorption: An ec-friendly alternative for heavy metal removal. Afr J Bio Techno 16: 292-31.

13. Tangahu B, Abdullah S, Rozaimah S, Basri H, Idris M, Anuar N \& Mukhlisin M (2011). A review on heavy metals (As, $\mathrm{Pb}$ and $\mathrm{Hg}$ ) uptake by plants through phytoremediation. Inter Jour of Chem Eng 107(2): 190-201.

14. Kumar VP, Chauhan NS, Padh H \& Rajani M (2006). Search for antibacterial and antifungal agents from selected Indian medicinal plants. $J$ of Ethnopharmaco 107(2): 182-188.

15. Dar RA, Shahnawaz M \& Qazi PH (2017). General overview of medicinal plants: A review. The $J$ of Phytopharmaco 6(6): 349-351.

16. Shinwari Z (2010). Medicinal plants research in Pakistan. $J$ of medi plants Res 4(3): 161-176.

17. Okalioglu S, Kartal S \& Elci L (2000). Determination of heavy metals and their speciation in lake sediments by flame atomic absorption spectrometry after a four-stage sequential extraction procedure. Analytica Chimica Acta 413(1-2): 33-40.
18. Nguyen G, Nguyen T, Le Thi NT, Truong PM \& Nguyen VM (2004). Application of atomic absorption spectrophotometry to determine $\mathrm{Cd}, \mathrm{Cu}, \mathrm{Pb}, \mathrm{Zn}$, in vegetable samples in Dalat (No. VAEC-AR--03).

19. Hughes $M$, Cowell $M$ \& Craddock $P$ (1976). Atomic absorption techniques in archaeology. Archaeometry 18(1): 1937.

20. Penner M (2017). Basic principles of spectroscopy. J. Food Compos Anal: 7988.

21. West M, Ellis AT, Potts PJ, Streli C, Vanhoof C \& Wobrauschek P (2014). Atomic Spectrometry. Update-a review of advances in X-ray fluorescence spectrometry. J Anal At Spectrom 29(9): 1516-1563.

22. Ali S \& Nasir E (1977). Flora of West Pakistan. No. 100, Papilionaceae. University of Karachi.

23. Dymock W, Warden $\mathrm{CH} \&$ Hooper D (1893). Pharmacographia Indica: A history of the principal drugs of vegetable origin, met with in British India (Vol 3): K. Paul, Trench, Trubner \& Company, Ltd.

24. Tietz S (1988). Revision von Astragalus L. sect. Campylanthus Bunge, sect. Microphysa Bunge und sect. Poterion Bunge Mitt Bot Staatssamml Munchen 27: 135-380.

25. Zafar M, Khan MA, Ahmad M, Jan G, Sultana S, Ullah K \& Abbasi AM (2010). Elemental analysis of some medicinal plants used in traditional medicine by atomic absorption spectrophotometer (AAS). $J$ of Medi Plants Res 4(19): 1987-1990.

26. Diaconu D, Diaconu R \& Navrotescu $\mathrm{T}$ (2012). Estimation of heavy metals in medicinal plants and their infusions. Analele Universitatii "Ovidius" Constanta-Seria Chimie 23(1): 115-120. 
27. Pahlsson AM (1989). Toxicity of heavy metals $(\mathrm{Zn}, \mathrm{Cu}, \mathrm{Cd}, \mathrm{Pb})$ to vascular plants. Water, Air and Soil Pollut 47(34): 287-319.

28. Khan KY, Khan MA, Niamat R, Munir M, Mazari HFP, Seema N \& Ahmed SN (2011). Element content analysis of plants of genus Ficus using atomic absorption spectrometer. Afri $J$ Phar Pharma 5(3): 317-321.

29. Obiajunwa EI, Adebajo AC \& Omobuwajo OR (2002). Essential and trace element contents of some Nigerian medicinal plants. J Radioana Nuc Chem 252(3): 473-476.

30. Shah A, Niaz A, Ullah N, Rehman A, Akhlaq M, Zakir M \& Suleman KM (2013). Comparative study of heavy metals in soil and selected medicinal plants. J chem.

31. Seghizzi P, D'Adda F, Borleri D, Barbic F \& Mosconi G (1994). Cobalt myocardiopathy. A critical review of literature. Sci Total Environ 150(1-3): 105-109.

32. Arnich N, Sirot V, Riviere G, Jean J, Noel L, Guerin T \& Leblanc JC (2012). Dietary exposure to trace elements and health risk assessment in the 2nd French Total Diet Study. Food \& Chem Toxico 50(7): 2432-2449.
33. Fuortes L \& Schenck D (2000). Marked elevation of urinary zinc levels and pleural-friction rub in metal fume fever. Veter \& Hum Toxico 42(3): 164-165.

34. Jarup L (2003). Hazards of heavy metal contamination. Brit Med Bull 68(1): 167182.

35. Hunt JR (2003). Bioavailability of iron, zinc, and other trace minerals from vegetarian diets. The Ame J Clin Nut 78(3): 6335-6395.

36. Todd GC (1996). Vegetables grown in mine wastes. Enviro Toxico \& Chem 19(3): 600-607.

37. Harper ME, Willis JS \& Patrick J (1997). Sodium and chloride in nutrition. 'Handbook of nutritionally essential mineral elements (Eds BL O'Dell, RA Sunde) pp 93-116.

38. Fernandes JC \& Henriques FS (1991). Biochemical, physiological and structural effects of excess copper in plants. The Botan Rev 57(3): 246-273.

39. Hess J \& Slavin J (2014). Snacking for a cause of nutritional insufficiencies and excesses of US children, a critical review of food conception patterns and macronutrients and micronutrients intake of US children. Nutrients 6(11): 4750-4759. 